\title{
Development of a New Combination Compound (Cyclopamine) Isolated from Veratrum californicum and 5-FU Acting as Anti-invasive and Initiator of Intrinsic Apoptosis Mechanism against Aggressive Type Colorectal Cancer Cells
}

\author{
Suwisit Manmuan ${ }^{1, *}$, Sukannika Tubtimsri ${ }^{2}$ and Ponwit Manmuan ${ }^{3}$ \\ ${ }^{I}$ Division of Pharmacology and Biopharmaceutical Sciences, Faculty of Pharmaceutical Sciences, \\ Burapha University, Chonburi 20131, Thailand \\ ${ }^{2}$ Division of Pharmaceutical Technology, Faculty of Pharmaceutical Sciences, Burapha University, \\ Chonburi 20131, Thailand \\ ${ }^{3}$ Department of Intellectual Property, Ministry of Commerce, Nonthaburi 11000, Thailand
}

("Corresponding author's e-mail: suwisit@buu.ac.th)

Received: 24 August 2020, Revised: 26 April 2021, Accepted: 24 May 2021

\begin{abstract}
Characteristics of programmed cell death are generally regarded as defined by cell outgrowth or cellular aging and distinct morphological characteristics featuring nuclear condensation and formation of apoptotic bodies. Apoptosis is considered to have a function at cellular level and is essential to long-lived cell differentiation undergoing senescence and apoptosis. Inappropriate apoptosis is a factor that results in serious conditions, causing multiple disease progression as well as cancer. The ability to modulate the life or death of a cancer cell is recognized for its immense therapeutic potential. Therefore, the research findings that are focused on the elucidation of a newly synthesized drug or drug derived from a natural plant to stop the cell cycle mechanism and signaling pathways that control cell cycle arrest and apoptosis are considered necessary. The field research of apoptosis is moving forward at a rapid rate. The goal of this paper is to investigate a natural active constituent, which is simply identified as "a drug for near future co-chemotherapy", as well as to explore the ability to activate the apoptotic pathway. Our results demonstrated that cyclopamine provides an excellent anti-tumor activity and changing of the morphology of cancerous cells in the early and late phases of apoptosis, indicating that cyclopamine has the potential to chemosensitize SW-620 cancer cells to 5-FU based chemotherapy, which may be useful for the treatment of colorectal cancer and the fight to overcome drug resistance in advanced colorectal cancer.
\end{abstract}

Keywords: Cyclopamine, Cell viability, Colorectal cancer, 5-fluorouracil, Invasive

\section{Introduction}

Colorectal cancer (CRC) is the most common cancer type that occurs in Thailand and the fourth leading cause of cancer-related death worldwide [1]. Surgical resection followed by chemotherapy or radiotherapy is still the main curative treatment for CRC patients. However, drug resistance and severe side effects that are remaining limit the effective treatment of most CRC patients [2]. 5-fluorouracil (5FU), an analog of uracil, is a chemotherapeutic drug for treatment in CRC patients. In cancer cells, 5-FU is converted to fluorodeoxyuridine monophosphate (FdUMP) to incorporate into DNA and RNA and also inhibit the activities of the thymidylate synthetase (TS) of the cancer cells, leading to cancer cell apoptosis $[3,4]$. Nonetheless, the overall response rate to 5-FU as a single drug in advanced CRC patients is approximately $10-15 \%$, which is still the main problem in CRC treatment [5]. Unfortunately, the metastatic cancer progressions are prolonged, highly invasive and refractory periods concurrent to chemotherapy. This inefficacy of current chemotherapy is an undesirable event in the protection against a locally invasive and metastatic cancer. The underlying problem is that the development of the novel therapeutic agent that can counteract cancer growth in its progression and overcome drug resistance for use as a long-term cancer therapy is urgently needed. Therefore, the further search for potential anticancer agents to overcome 5-FU resistance and resistance reversal to 5-FU is important. Recently, 5-FU combined with novel anti-cancer agents such as oxaliplatin, irinotecan, and resveratrol were found to improve the response rates to $40-50 \%$ and also decrease the unwanted side effects of these drugs [5-7]. 
These findings indicated that 5-FU could be suitable for combination with other anti-cancer agents for improving the efficacy of treatment. A combination method using drugs and active compounds from natural sources is becoming a common way to identify a highly effective drug development and focus on drug/co-chemotherapy to attack cancerous cells. Natural plant extracts are enriched phytochemical constituents that could amplify the effectiveness of current drug chemotherapy with minimal side effects. In this present study, the assessment of the ability of natural products to induce apoptosis and influence the growth power in cancer cells was carried out. The results of this study provide data regarding the antitumor activity of cyclopamine in colorectal cancer cells.

Cyclopamine $(\mathrm{Cm})$ is a naturally occurring steroidal alkaloid which isolated from the corn lily plant, primarily found in its roots and rhizomes [8]. Chemical structures of cyclopamine were represented in Figure 1. Its analogues may be used for a variety of applications in cancer therapy $[9,10]$. A recent study demonstrated that cyclopamine functions as a hedgehog signaling pathway inhibitor in pancreatic cancer cells [11]. Moreover, cyclopamine increases the cytotoxic effects of paclitaxel and radiation but not cisplatin and gemcitabine in hedgehog expressing pancreatic cancer cells [12]. In addition, cyclopamine was shown to inhibit proliferation and to induce apoptosis, as well as to inhibit expression of a Glidependent luciferase reporter in sensitive cell lines [13]. Recent studies have established the therapeutic benefit of co-targeting the epidermal growth factor receptor (EGFR) and sonic hedgehog pathways by using gefitinib and cyclopamine, for improving the efficacy of the current chemotherapeutic drug, docetaxel, to counteract prostate cancer (PC) progression from the locally invasive to metastatic and recurrent disease stages [14]. Moreover, cyclopamine cooperates with EGFR inhibition to deplete stemlike cancer cells in glioblastoma-derived spheroid cultures, suggesting that the synergistic efficacy of erlotinib-cyclopamine association could be a suitable regimen in glioblastoma cancer [15]. Additionally, co-administration of polymeric conjugates of docetaxel and cyclopamine synergistically inhibits orthotopic pancreatic cancer growth and metastasis [16]. Therefore, the objective of the present study is to determine the anti-cancer effect of cyclopamine on cell viability and cell invasion and to evaluate the combination effects of cyclopamine and 5-FU on cell survival in SW-620 human colorectal cancer cells.

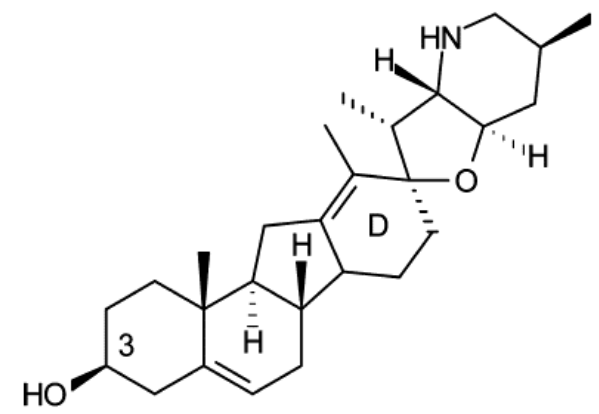

Figure 1 Chemical structures of cyclopamine [17].

This study was performed to primarily investigate the cytotoxicity of cyclopamine on human colorectal cancer cells. For example, the results show that cyclopamine has significant toxicity on the cell viability of SW-620 cells with the range of cyclopamine between $1-50 \mu \mathrm{g} / \mathrm{mL}$ after treatment for 24,48 and $72 \mathrm{~h}$. According to microscopic examination, cyclopamine could change the morphological characteristics of cancerous cells by inducing rounded shapes and packing chromatin condensation following detachment of cancer cells from the cultured plate, which suggests that cells lost adhesive ability and that there was disruption of cell adherence to their basal membrane. Moreover, this compound can be precisely generated for powerful effects with the long-used medicine 5-FU to diminish the proliferation of aggressive cells in experiments. All of these results strengthen the conclusion that the use of cyclopamine alone or in combination with 5-FU, consistent with previously studies, can provide the robust anti-cancer effects of cyclopamine that block various types of cancer progression and carcinogenesis. 


\section{Materials and methods}

\section{Cell cultures and reagents}

SW-620 human colorectal cancer cell lines (ATCC ${ }^{\circledR}$ Number: CCL-227 ${ }^{\mathrm{TM}}$ ) were purchased from American Type Culture Collection (ATCC, USA). SW-620 monolayer cells were maintained in RPMI1640 (Invitrogen, USA) supplemented with $10 \%$ heat inactivated fetal bovine serum (FBS) (Gibco, USA), $100 \mathrm{U} / \mathrm{mL}$ penicillin, $100 \mu \mathrm{g} / \mathrm{mL}$ of streptomycin and amphotericin $\mathrm{B}$ in a humidified $37{ }^{\circ} \mathrm{C}$ incubator containing $5 \% \mathrm{CO}_{2}$. MRC-5 normal fibroblast cells were kindly provided by Dr. Sukannika Tubtimsri, Division of Pharmaceutical Technology, Faculty of Pharmaceutical Sciences, Burapha University. Cells were cultured in DMEM media supplemented with $10 \% \mathrm{FBS}, 100 \mathrm{U} / \mathrm{mL}$ penicillin, 100 $\mu \mathrm{g} / \mathrm{mL}$ of streptomycin and amphotericin $\mathrm{B}$ in the $\mathrm{CO}_{2}$ incubator. Cells were grown in a T-25 cell culture flask until the $90 \%$ confluence as well as the late phase of growth. Cells were trypsinized by trypsinEDTA to remove cells adhering to the culture flask. Cells that were used in the experiment were counted by the trypan blue dye solution method to quantify the number of cells seeding in the culture wells. Cell viability at $95 \%$ was used in the experiments. Cyclopamine and 5-FU (AMRESCO, USA) were purchased from Sigma-Aldrich and dissolved in absolute DMSO and methanol, respectively. A stock solution of $1,000 \mu \mathrm{g} / \mathrm{mL}$ of cyclopamine was kept away from light and stored at $-20^{\circ} \mathrm{C}$. Stock solutions were newly prepared by dilution with RPMI-1640 media to the final concentrations.

\section{Morphological observation}

SW-620 cells were seeded in a 24-well plate at a density of 100,000 cells/well for 24 and $48 \mathrm{~h}$. The medium was aspirated from the culture plate by pipette aid. Cells were cultured with cyclopamine at 5,10 and $25 \mu \mathrm{g} / \mathrm{mL}$ for 24 and $48 \mathrm{~h}$. Treated cells were observed for morphological changes after exposure to cyclopamine by a $100 \times$ magnification light microscope (Olympus, Japan).

\section{MTT cell viability assay}

Cells were seeded at a density of 5,000 cells/well into a 96-well plate and incubated at $37{ }^{\circ} \mathrm{C}$ in a 5 $\% \mathrm{CO}_{2}$ atmosphere for $24 \mathrm{~h}$. Cells were treated with $1,5,10,25$ and $50 \mu \mathrm{g} / \mathrm{mL}$ of cyclopamine in triplicate for 24, 48 and $72 \mathrm{~h}$. Cells were treated with 1, 10 and $100 \mu \mathrm{g} / \mathrm{mL}$ of 5 -FU used as positive control in the experiment. Then, $10 \mu \mathrm{L}$ of $5 \mathrm{mg} / \mathrm{mL}$ 3-4,5-Dimethyl-2-thiazolyl-2,5-diphenyl-2Htetrazolium bromide (MTT) (AMRESCO, USA) in PBS solution was added into each well and incubated at $37^{\circ} \mathrm{C}$ for $3 \mathrm{~h}$. Mitochondrial dehydrogenase in viable cells can metabolize the yellow color of MTT to purple formazan crystal, which is solubilized by DMSO and measured by spectrophotometer. The cultured medium was aspirated and a $100 \mu \mathrm{L}$ aliquot of DMSO (Sigma, USA) was then added and absorbance was measured by a microplate reader at a wavelength of 550 nanometers. Cell viability in treated cells are proportional to the reading of absorbance compared with the reading of absorbance in untreated cells. Data was presented as the percentage of cell viability, which was calculated using the following equation;

$\left(\mathrm{OD}_{\text {sample }}-\mathrm{OD}_{\text {blank }} / \mathrm{OD}_{\text {control }}-\mathrm{OD}_{\text {blank }}\right) \times 100 \%$

\section{Drug combination assay}

Drug combination experiments were carried out by MTT assay. Briefly, cells were seeded at a density of 5,000 cells/well into a 96-well plate and maintained at $37{ }^{\circ} \mathrm{C}$ in a $5 \% \mathrm{CO}_{2}$ atmosphere for 24 $\mathrm{h}$. The medium was aspirated from each well to prepare different concentrations of cyclopamine and 5FU by serial dilution from the stock solution $(1,000 \mu \mathrm{g} / \mathrm{mL})$. Cells were treated with a combination of 1 , $2.5,5,7.5,10,25$ and $50 \mu \mathrm{g} / \mathrm{mL}$ of $5-\mathrm{FU}$ and 10 and $20 \mu \mathrm{g} / \mathrm{mL}$ of cyclopamine for $48 \mathrm{~h}$. Following the drug exposure period, $10 \mu \mathrm{l}$ of MTT in PBS solution was added to the developed formazan crystals form, which was solubilized by absolute DMSO. The plates were shaken and rapidly analyzed using a microplate reader. The density of the formazan product after solubilization is directly proportional to the number of living cells.

\section{Drug combination index analysis}

This method was used to determine the synergistic, additive, and antagonistic drug-drug interactions between cyclopamine and 5-FU. The MTT colorimetric assay was repeated to determine the $\mathrm{IC}_{50}$ values of 5-FU treatment alone and 5 -FU $+10 \mu \mathrm{g} / \mathrm{mL}$ of cyclopamine for $48 \mathrm{~h}$. Combination index values were determined using the following equation by the Chou-Talalay method: $C I=\left(\left(C_{50}\right) \mathrm{a} /\left(\mathrm{IC}_{50}\right) \mathrm{a}+\right.$ $\left.\left(\mathrm{C}_{50}\right) \mathrm{b} /\left(\mathrm{IC}_{50}\right) \mathrm{b}\right) .\left(\mathrm{C}_{50}\right) \mathrm{a}$ and $\left(\mathrm{C}_{50}\right) \mathrm{b}$ are the concentrations of cyclopamine and 5-FU that were used for the 
inhibition of cell viability at $50 \%$. $\left(\mathrm{IC}_{50}\right) \mathrm{a}$ and $\left(\mathrm{IC}_{50}\right) \mathrm{b}$ are the concentrations of each compound, which reduced cell viability by $50 \%$. CI values were interpreted as the following: synergism $(\mathrm{CI}<1)$, additive $(\mathrm{CI}=1)$, antagonism $(\mathrm{CI}>1)$, respectively.

\section{Wound scratch assay}

Cells were seeded in a 24-well plate in RPMI-1640 containing $10 \%$ FBS until reaching $100 \%$ confluence to form monolayers. To exclude the growth factor in the fetal bovine serum (FBS), cells were routinely washed with phosphate buffer saline (PBS) to produce the minimal growth factor. Cell monolayers were scratched with a $200 \mu \mathrm{L}$ micropipette tip to generate a wound. The culture medium was withdrawn from the 24-well plate and washed with PBS solution to remove floating cells and was captured with an inverted microscope (objective $5 \times$ ) at time 0 . Cells were cultured with $20 \mu \mathrm{g} / \mathrm{mL}$ of cyclopamine and $20 \mu \mathrm{g} / \mathrm{mL}$ of cyclopamine $+20 \mu \mathrm{g} / \mathrm{mL}$ of 5 -FU in RPMI-1640 containing $5 \%$ FBS. The cells were then photographed at time 0,24 and $48 \mathrm{~h}$.

\section{Matrigel-coated invasion chamber assay}

Cells were seeded at a density of 50,000 cells/well for $24 \mathrm{~h}$ in a $5 \% \mathrm{CO}_{2}$ atmosphere and then treated with $20 \mu \mathrm{g} / \mathrm{mL}$ of cyclopamine and $20 \mu \mathrm{g} / \mathrm{mL}$ of cyclopamine $+20 \mu \mathrm{g} / \mathrm{mL}$ of 5 -FU for $48 \mathrm{~h}$. The polycarbonate membrane was coated with matrigel $(0.5 \mathrm{mg} / \mathrm{mL}$; BD Biosciences, San Jose, CA $)$ and dried overnight in a laminar flow cabinet. Cells were trypsinized by trypsin-EDTA and seeded into the matrigel-coated invasion chamber (pore size: $8 \mu \mathrm{M}$; Corning, Cambridge, MA). The lower chamber of the system was filled with a $500 \mu \mathrm{L}$ RPMI-1640 medium containing $10 \%$ FBS as a chemoattractant. After $48 \mathrm{~h}$ incubation, non-invading cells on the upper surface of the invasion chamber were wiped off with a cotton swab. Cells that migrated through the matrigel and across the invasion chamber were fixed with ice-cold methanol (AMRESCO, USA) and stained with crystal violet (Sigma, USA) for $30 \mathrm{~min}$. Cells were photographed with an inverted microscope (Olympus, Japan) and counted in 5 random fields. Data were expressed as \% proportional invasiveness comparing treated cells with untreated cells.

\section{Caspase-3 activity measurement}

The caspase- 3 activities were determined by the Caspase- 3 Assay Kit, Colorimetric, according to the manufacturer's instructions. Cells were cultured in a 24-well plate for $24 \mathrm{~h}$ and then treated with cyclopamine at $5,10,15$ and $25 \mu \mathrm{g} / \mathrm{mL}$ for $48 \mathrm{~h}$. The cell lysates were resuspended in lysis buffer for 30 min on ice. The supernatants were collected for the assay. The $1 \times$ assay buffer was added to each well. Caspase- 3 inhibitor was added to wells, then caspase- 3 substrate was added and mixed gently at $37{ }^{\circ} \mathrm{C}$ in the dark for $2 \mathrm{~h}$. The formation of p-nitroanilide (pNA) was read at $405 \mathrm{~nm}$ by the ELISA plate reader (Metertech, Taiwan). The data were represented as fold of control.

\section{Toxicity assessment in normal cells}

MRC-5 fibroblast normal cells at a density of 5,000 cells/well were cultured with DMEM medium in a 96-well plate. Cells were incubated with cyclopamine at 1, 2.5, 5, 10 and $25 \mu \mathrm{g} / \mathrm{mL}$ for $24 \mathrm{~h}$. Cell survival after being treated with cyclopamine was determined using MTT cell viability assay. OD values were read by microplate reader at $550 \mathrm{~nm}$. The percentage of cell viability was determined and graphs of cell viability compared to untreated cells were generated.

\section{Statistical analysis}

The data analysis was performed for 3 experiments $(n=3)$, Data were expressed as means \pm SEM from 3 independent experiments analyzed by one-way ANOVA with Tukey's Honestly Significant Difference (HSD) post hoc test by GraphPad Prism software. The $p$-values less than 0.05 were considered as statistically significant. All graphs were generated to analyze the results using GraphPad Prism software Ver. 7.0.

\section{Results and discussion}

\section{Cell morphological change after treatment with cyclopamine}

This study focused on SW-620 cell morphology after placing cells in RPMI-1640 medium containing cyclopamine at 5,10 and $25 \mu \mathrm{g} / \mathrm{mL}$ for $24 \mathrm{~h}$. As shown in Figure 2, cells were captured by light microscope at $100 \times$ magnification to analyze the morphological change after being treated with cyclopamine as well as testing the cyclopamine derived from HPLC isolation to check the preliminary activity of cyclopamine in cancer cell lines. The results showed that cancer cells which were tested with 
$25 \mu \mathrm{g} / \mathrm{mL}$ of cyclopamine showed loss of cell morphology from epithelial cancer cells to rounded cells as well as cells in the steady-state apoptosis phase of the cell cycle compared with the control group. Nuclear condensation and characteristic apoptotic features were visualized after cells were treated with cyclopamine at $25 \mu \mathrm{g} / \mathrm{mL}$. In additional images at 5 and $10 \mu \mathrm{g} / \mathrm{mL}$ of cyclopamine, morphological change in cells was not found. This study demonstrated that cyclopamine in low dose concentrations affected the cell morphology and may have an effect on the cells adhering in the cell culture plate.

Cytomorphological alteration was investigated by bright field light microscope. The morphology of SW-620 cells was significantly changed into rounded cells and chromatin condensation, which is a characteristic feature of apoptosis that can be observed after treating cells. Disorganized cytoplasmic organelles was observed after the SW-620 cells treatment with cyclopamine at $25 \mu \mathrm{g} / \mathrm{mL}$ for $48 \mathrm{~h}$ (Figure 3). While the untreated control cells remained in epithelial cell shape and certainly adhered to the culture well, in other images, after treatment with cyclopamine at 5 and $10 \mu \mathrm{g} / \mathrm{mL}$ apoptotic cells were not found. However, after treatment of SW-620 cells at $48 \mathrm{~h}$, in those treated with $10 \mu \mathrm{g} / \mathrm{mL}$ of cyclopamine, slight apoptosis of cancer cells was found. These results demonstrated that cyclopamine at $25 \mu \mathrm{g} / \mathrm{mL}$ can induce the apoptosis process in cancer cells. Regarding the intrinsic and extrinsic pathway involvement of apoptotic induction, the molecular mechanism underlying cell death and characteristic features in programmed cell death should be further investigated in order to provide an explanation in their study. Consistently, cyclopamine and quercetin suppressed cell growth and induced apoptosis in 7 and 8 leukemia and lymphoma cell lines. The possible mechanism that is responsible for their effect was established by cyclopamine decreasing the level of the Gli1 protein, a target gene product of Hh signaling [18].

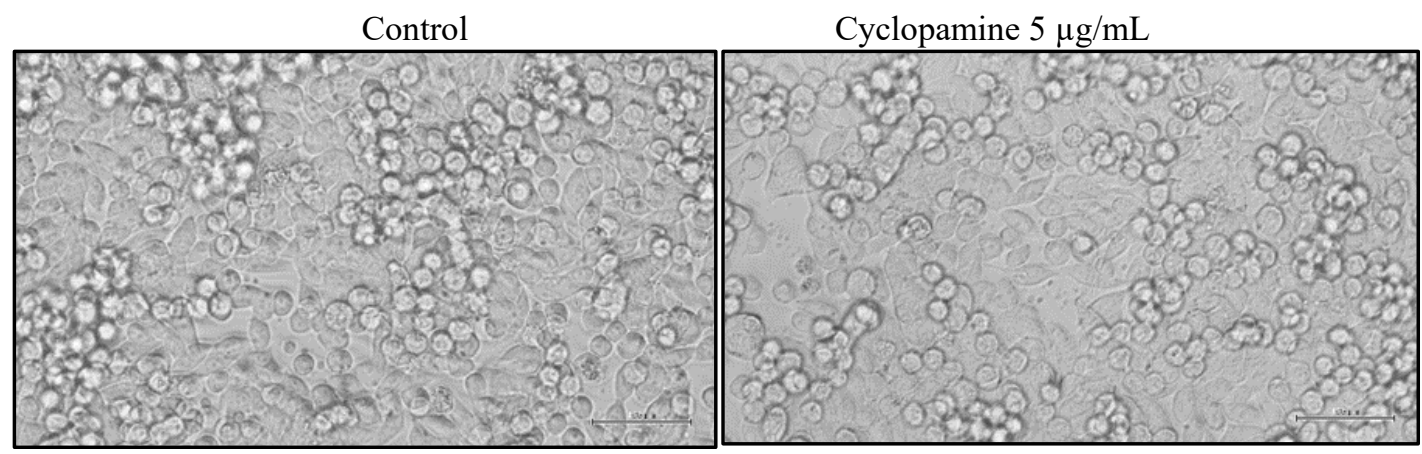

Cyclopamine $10 \mu \mathrm{g} / \mathrm{mL}$

Cyclopamine $25 \mu \mathrm{g} / \mathrm{mL}$

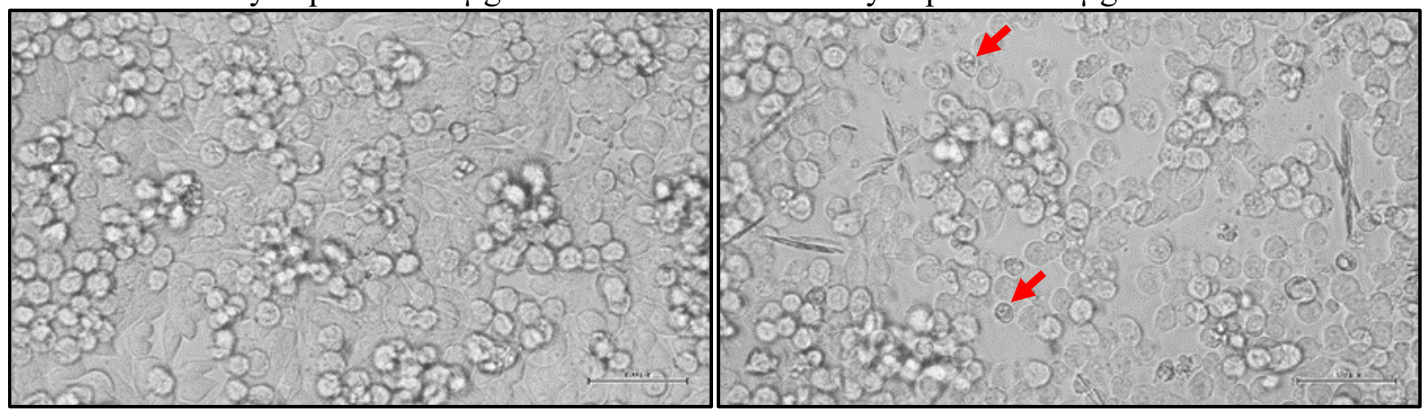

Figure 2 Effect of cyclopamine on cell morphology in SW-620 colorectal cancer cells. Cells were tested with 5,10 and $25 \mu \mathrm{g} / \mathrm{mL}$ of cyclopamine for $24 \mathrm{~h}$. Cells were photographed with an inverted microscope at a magnification of $100 \times$ and observed to determine cell morphological changes after cyclopamine treatment. 

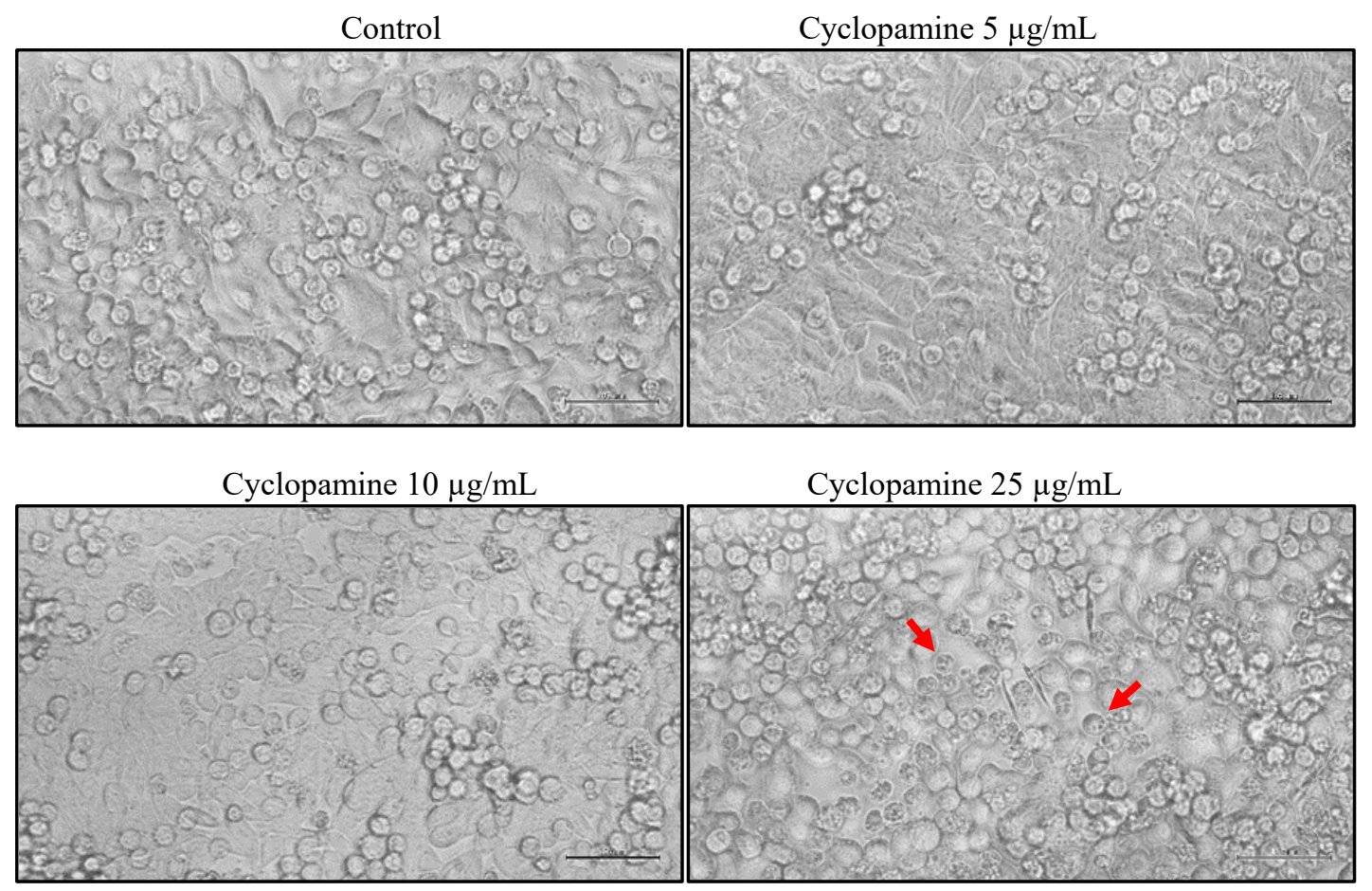

Figure 3 Effect of cyclopamine on cell morphology in SW-620 colorectal cancer cells. Cells were tested with 5,10 and $25 \mu \mathrm{g} / \mathrm{mL}$ of cyclopamine for $48 \mathrm{~h}$. Cells were photographed with an inverted microscope at a magnification of $100 \times$ and observed to determine cell morphological changes after cyclopamine treatment.

\section{Anti-cancer activity of cyclopamine on cell viability of SW-620 colorectal cancer cells}

Cells were treated with $1,5,10,25$ and $50 \mu \mathrm{g} / \mathrm{mL}$ of cyclopamine for 24,48 and $72 \mathrm{~h}$. As shown in Figure 4, cyclopamine significantly inhibited cell viability in a dose- and time-dependent manner. In particular, cyclopamine at 25 and $50 \mu \mathrm{g} / \mathrm{mL}$ significantly decreased cell viability in cancer cells $(p<$ $0.001)$. The $\mathrm{IC}_{50}$ values at 24,48 and $72 \mathrm{~h}$ were $30.85 \pm 2.439,23.67 \pm 0.2672$ and $22.15 \pm 2.637 \mu \mathrm{g} / \mathrm{mL}$ respectively (Table 1). Interestingly, at $72 \mathrm{~h}$ treatment, the ability of cyclopamine at $50 \mu \mathrm{g} / \mathrm{mL}$ to reduce the cell viability of cancer cells was not different from that of 5-FU $100 \mu \mathrm{g} / \mathrm{mL}$. These results indicated that a low dose of cyclopamine can strongly inhibit cell survival in colorectal cancer cells. This is consistent with previous reports that cyclopamine suppressed the growth of endometrial carcinoma cells and acute B-lymphoblastic leukemia cells [19,20].

(a)

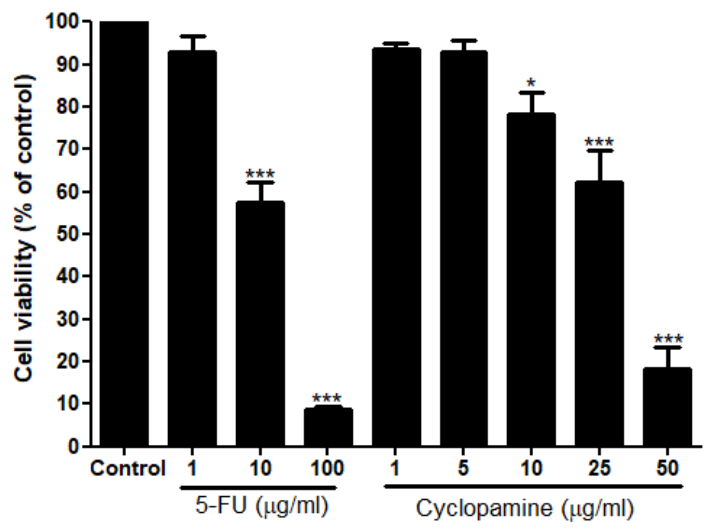

Test compounds (b)

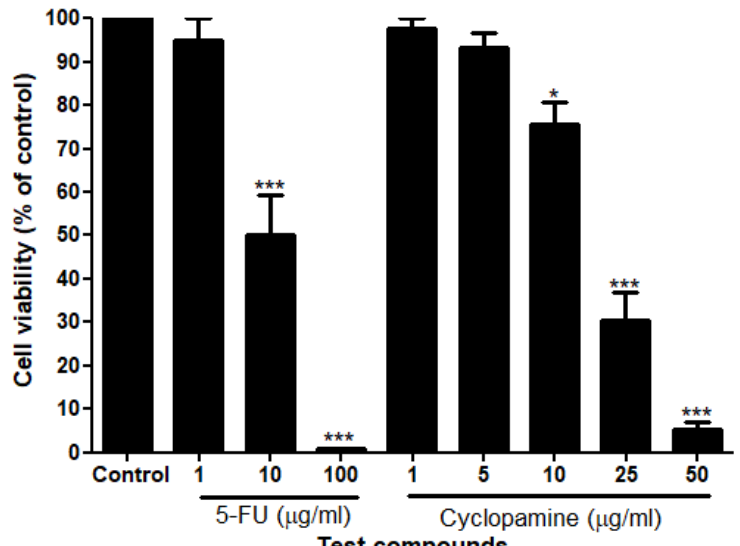

Test compounds 
(c)

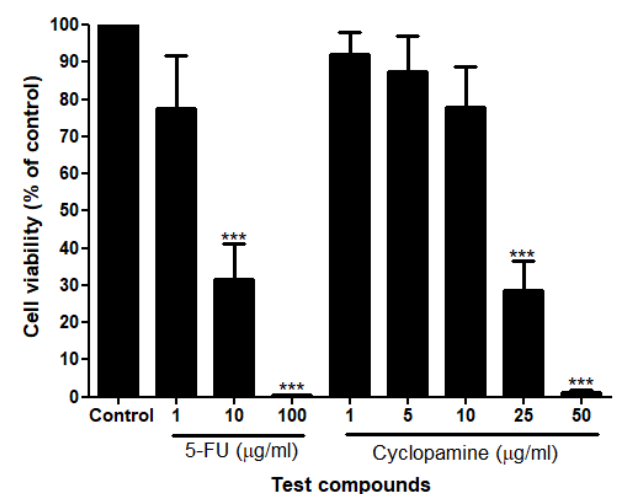

(d)

(e)

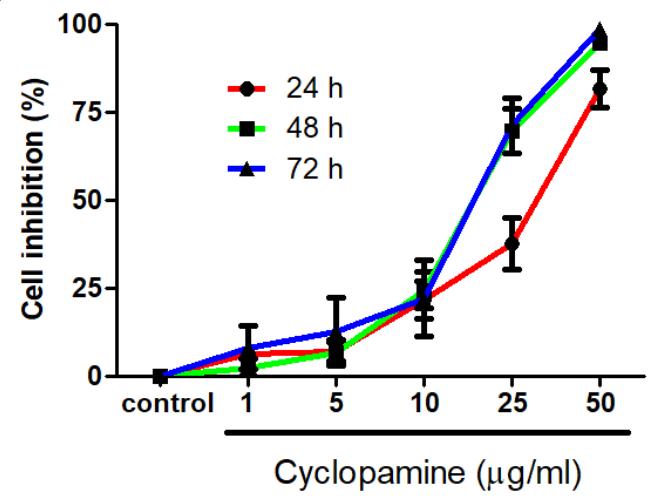

Figure 4 Inhibitory effect of cyclopamine on cell viability of SW-620 colorectal cancer cells. Cells were treated with 1, 5, 10, 25 and $50 \mu \mathrm{g} / \mathrm{mL}$ of cyclopamine for 24 (Figure 4(a)), 48 (Figure 4(b)), and 72 (Figure 4(c)) h. The percentage of cell viability (Figure 4(d)) and cell inhibition (Figure 4(e)) were plotted to represent the different times of cyclopamine effectiveness. Cells were treated with various concentrations of 5-FU $(1,10$ and $100 \mu \mathrm{g} / \mathrm{mL})$ using a positive control in the experiment. Cell viability was determined by MTT cell viability assay. The data were expressed as Mean $\pm \operatorname{SEM}(\mathrm{n}=3)$. ${ }^{* * *} p<$ 0.001 , significantly different from the control, $* p<0.05$, significantly different from the control

Table 1 Calculation of the inhibitory concentration values $\left(\mathrm{IC}_{25}, \mathrm{IC}_{50}, \mathrm{IC}_{75}\right)$ of cyclopamine decreased cell viability after treatment for 24,48 and $72 \mathrm{~h}$ in SW-620 colorectal cancer cells.

\begin{tabular}{cccc}
\hline Cell lines (SW-620) & \multicolumn{4}{c}{ Cytotoxicity of cyclopamine at 25, 50 and 75 \% inhibition } \\
\hline Times $(\mathrm{h})$ & $\mathrm{IC}_{25}(\mu \mathrm{g} / \mathrm{mL})$ & $\mathrm{IC}_{50}(\mu \mathrm{g} / \mathrm{mL})$ & $\mathrm{IC}_{75}(\mu \mathrm{g} / \mathrm{mL})$ \\
\hline 24 & $14.84 \pm 1.682$ & $30.85 \pm 2.439$ & $46.86 \pm 3.297$ \\
\hline 48 & $11.19 \pm 0.2442$ & $23.67 \pm 0.2672$ & $36.15 \pm 0.4164$ \\
\hline 72 & $9.735 \pm 3.175$ & $22.15 \pm 2.637$ & $34.56 \pm 2.123$ \\
\hline
\end{tabular}

*** Each value was represented as mean \pm SEM from 3 independent experiments $(\mathrm{n}=3)$. cells

Effect of cyclopamine with 5-FU on the inhibition of cell viability in SW-620 colorectal cancer

5-FU is widely used as a standard therapy in the management of colorectal cancer. However, the problem that occurs in 5-FU treatment is that $50 \%$ of patients show resistance to 5 -FU. Therefore, the identification of a novel anti-cancer agent from natural sources that can sensitize cancer cells to chemotherapeutic drugs in colorectal cancer treatment is challenging. As shown in Figure 5, cells were treated with a wide range of 5-FU concentrations from 1, 2.5, 5, 7.5, 10 and 25 to $50 \mu \mathrm{g} / \mathrm{mL}$ and 5 -FU combined with low doses of cyclopamine at 10 and $20 \mu \mathrm{g} / \mathrm{mL}$. The drug combination assay demonstrated that the cell viability of SW-620 cells was effectively decreased after being co-treated with a low dose of cyclopamine and 5-FU, in comparison to the 5-FU single treatment. As shown in Table 2, demonstrated 
the IC values at $25,50,75 \%$ after co-treatment. The results indicated that cyclopamine $10 \mu \mathrm{g} / \mathrm{mL}$ can increase the response rate of SW-620 cells to the effectiveness of 5-FU. In addition, the higher concentration of cyclopamine at $20 \mu \mathrm{g} / \mathrm{mL}$ can be used to explore the excellently concomitant effectiveness with established 5-FU after treatment for $48 \mathrm{~h}$. The drug relationship between cyclopamine and 5-FU was shown to have a synergistic effect. In addition, the CI value of $10 \mu \mathrm{g} / \mathrm{mL}$ of cyclopamine combined with 5-FU is 0.968 , which can be interpreted to indicate that the interaction between cyclopamine and 5-FU was synergistic (Table 3). These results suggest that 5-FU combined with cyclopamine can synergistically reduce colorectal cancer cells survival and proliferation. In this study, we demonstrated the effect of cyclopamine on the inhibition of cell viability and the increase of the cytotoxic effect of 5-FU in colorectal cancer cells. The results demonstrated that cyclopamine combined with 5-FU act as synergistic agents that greatly reduce cell proliferation in colorectal cancer cells.

(a)

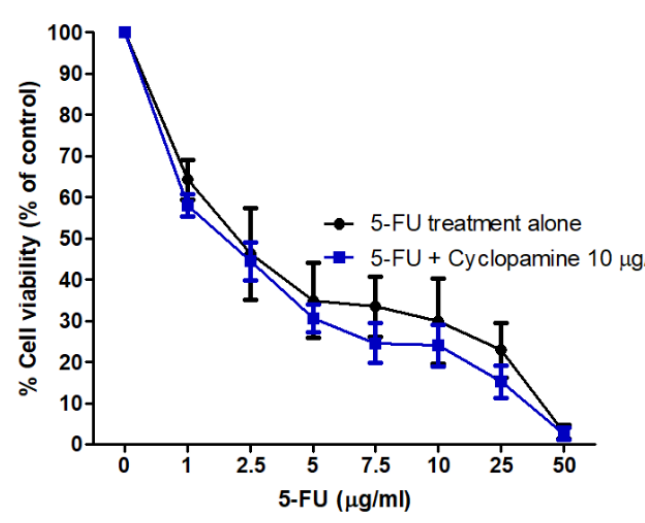

(c)

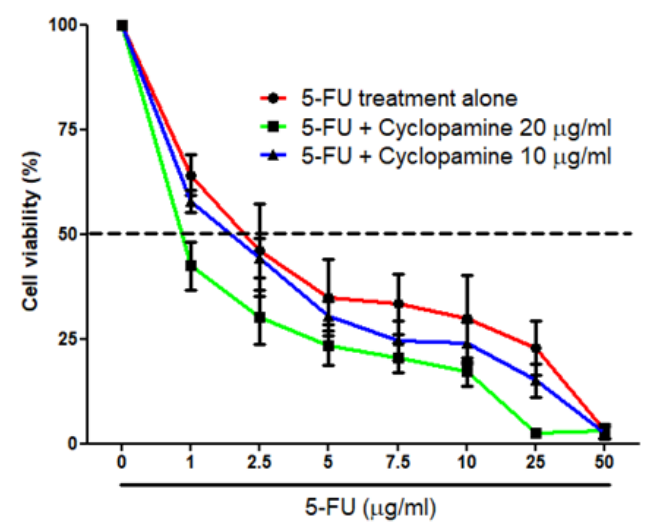

(b)

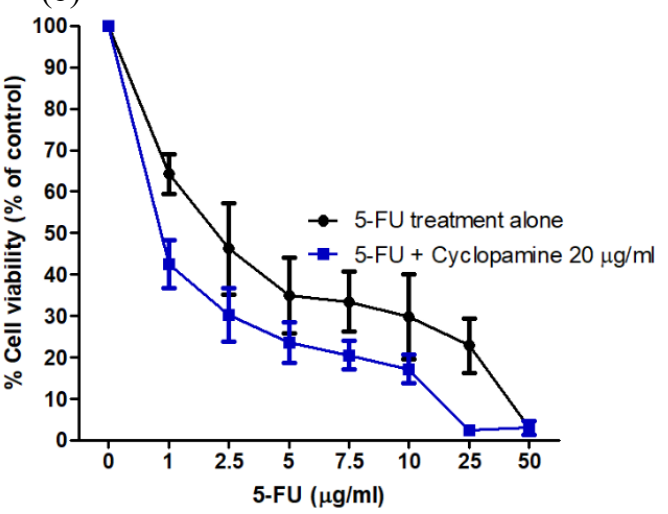

(d)

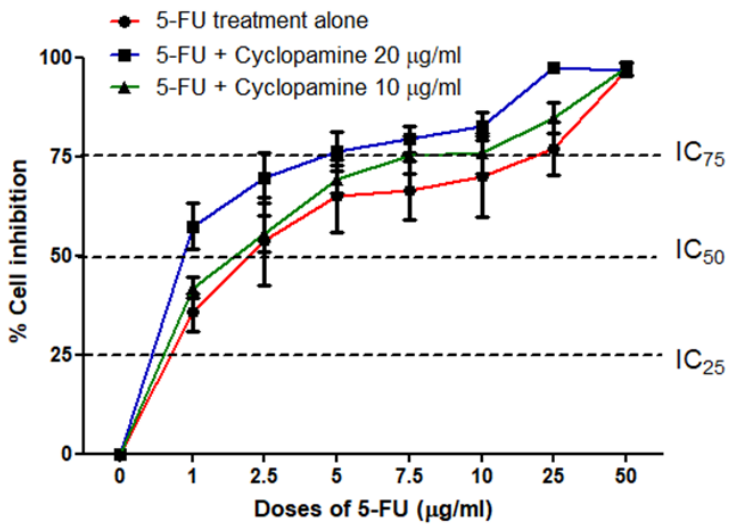

Figure 5 Synergistic effect of 5-FU with cyclopamine on the inhibition of cell viability in SW-620 colorectal cancer cells. Cells were treated with a range of concentrations of 5-FU and cyclopamine at 10 (Figure 5a) and 20 (Figure 5b) $\mu \mathrm{g} / \mathrm{mL}$ for $48 \mathrm{~h}$. Cell viability was evaluated by MTT cell viability assay. The data were expressed as Mean $\pm \operatorname{SEM}(n=3)$.

Table 2 Calculation of the inhibitory concentration values $\left(\mathrm{IC}_{25}, \mathrm{IC}_{50}, \mathrm{IC}_{75}\right)$ of cyclopamine decreased cell viability after co-treatment with 5-FU for $48 \mathrm{~h}$ in SW-620 colorectal cancer cells.

\begin{tabular}{cccc}
\hline Cell lines (SW-620) & \multicolumn{3}{c}{ Inhibitory Concentration of Cyclopamine + 5-FU } \\
at 25, 50 and 75 \%o \\
Time 48 h & $\mathrm{IC}_{25}(\mu \mathrm{g} / \mathrm{mL})$ & $\mathrm{IC}_{50}(\mu \mathrm{g} / \mathrm{mL})$ & $\mathrm{IC}_{75}(\mu \mathrm{g} / \mathrm{mL})$ \\
\hline 5-FU treatment alone & $0.930 \pm 0.565$ & $4.168 \pm 1.023$ & $7.512 \pm 1.436$ \\
\hline 5-FU + Cyclopamine $20 \mu \mathrm{g} / \mathrm{mL}$ & $0.1793 \pm 0.003$ & $2.294 \pm 0.550$ & $4.601 \pm 1.001$ \\
\hline 5-FU + Cyclopamine $10 \mu \mathrm{g} / \mathrm{mL}$ & $0.4498 \pm 0.211$ & $3.422 \pm 0.373$ & $6.381 \pm 0.559$ \\
\hline
\end{tabular}

*** Each value was represented as mean \pm SEM from 3 independent experiments $(\mathrm{n}=3)$. 
Table 3 The $\mathrm{IC}_{50}$ values and combination index (CI) values for either 5-FU treatment alone or combined with $10 \mu \mathrm{g} / \mathrm{mL}$ of cyclopamine in SW-620 human colorectal cancer cells after treatment for $48 \mathrm{~h}$.

\begin{tabular}{cccc}
\hline Test compound & IC $_{\mathbf{5 0}}(\boldsymbol{\mu g} / \mathbf{m L})$ & CI value & Description \\
\hline Cyclopamine & 23.67 & - & - \\
\hline 5-FU treatment alone & 2.774 & - & - \\
\hline $5-\mathrm{FU}+$ Cyclopamine $10 \mu \mathrm{g} / \mathrm{mL}$ & 1.516 & 0.968 & synergism \\
\hline
\end{tabular}

${ }^{*} \mathrm{CI}<1, \mathrm{CI}=1$, and $\mathrm{CI}>1$ were synergism $(\mathrm{CI}<1)$, additive $(\mathrm{CI}=1)$, and antagonism $(\mathrm{CI}>1)$, respectively.

*** Each value was received from triplicates and 3 independent experiments $(n=3)$.

Compatibility in drug-drug interaction is a desirable reaction when combinative treatment between a drug and another drug is applied in experiments. Physical incompatibility is determined by a simple examination that can identify manifest appearance in these interactions by turbidity and color change. In this present study, a simple visual observation of the cyclopamine and 5-FU mixture in the 96-well plate did not show the presence of dissolution or phase separation and precipitation after combinative treatment of cells, suggesting that the interaction of cyclopamine and 5-FU is physically compatibility in drug combination treatment.

\section{Effect of cyclopamine with 5-FU on the inhibition of cell migration in SW-620 colorectal cancer cells}

In Figure 6, the effects of cyclopamine on the inhibition of cell migration in SW-620 cells are presented. Cells were scratched with a $200 \mu \mathrm{L}$ pipette tip to generate wounds. Cells were treated with cyclopamine alone and concurrently treated with 5-FU to monitor the rate of migrative inhibition. The number of cells in the active state to repair the wound scratches were captured with an inverted microscope to calculate the number of cell migration and automated cell count by Image J software. The results demonstrated that the migratory ability of SW-620 cells was dramatically decreased after treatment with cyclopamine and co-treatment with 5-FU combination. After $48 \mathrm{~h}$ of incubation time, the ability of cells to repair the wounds opened from scratches $(p<0.01)$ was significantly decreased.

(a)

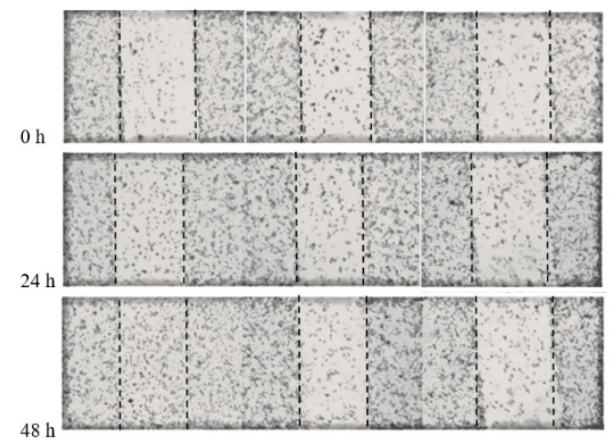

(b)

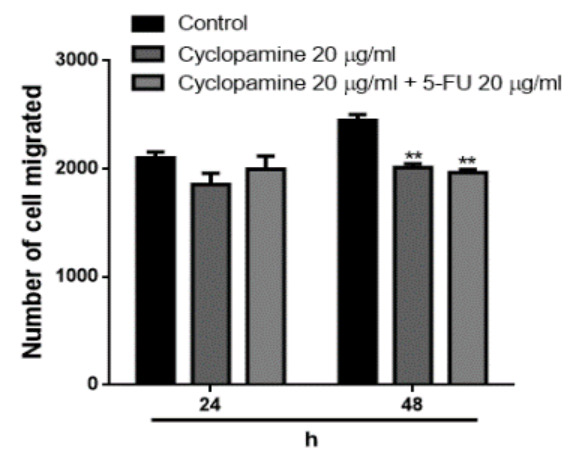

Figure 6 Effects of cyclopamine with 5-FU on cell migration in SW-620 colorectal cancer cells. The monolayers were scratched with a $200 \mu \mathrm{L}$ pipette tip to generate wounds. Cells were cultured in the presence of $20 \mu \mathrm{g} / \mathrm{mL}$ of cyclopamine and combined with $20 \mu \mathrm{g} / \mathrm{mL}$ of 5 -FU for $48 \mathrm{~h}$ (Figures 6(a) 6(b)). The images were captured at time 0,24 and $48 \mathrm{~h}$. The data were expressed as Mean $\pm \operatorname{SEM}(\mathrm{n}=3)$. ** $p<0.01$, significantly different from the control.

Effect of cyclopamine with 5-FU on the inhibition of cell invasion and caspase-3 activity in SW-620 colorectal cancer cells

Matrigel invasion assay were performed to determine the effect of cyclopamine on the ability of aggressive cancer cells through degrading the extracellular matrix. The results demonstrated that cells which were treated with $20 \mu \mathrm{g} / \mathrm{mL}$ cyclopamine showed depleted ability in migration through matrigel. The percentage of invasion was $74.44 \pm 5.24 \%(p<0.01)$. In drug co-treatment, it was demonstrated that cyclopamine with 5-FU exhibited the synergistic drug activity that highly depreciated the ability to invade 
through matrigel. The percentage of cell invasion was $67.38 \pm 6.09 \%(p<0.01)$. Therefore, this regimen may be used as a drug to minimize the invasive capacity of aggressive cancer. These results indicated that cyclopamine may be an anti-invasive agent for colorectal cancer patients (Figures 7(a) - 7(b)).

As recently reported, cyclopamine reduces beta-Catenin-Tcf transcriptional activity, induces ECadherin expression, and reduces invasion in colorectal cancer cells [22]. In another report, it was demonstrated that cyclopamine is a novel Hedgehog signaling inhibitor with significant anti-proliferative, anti-invasive and anti-estrogenic potency in human breast cancer cells [23]. Apoptosis, which is the particularly critical event mechanism for cell death, is sophisticatedly complex, involving the inducing of numerous cascades of molecular events [24]. Apoptosis activation is typically responsible as a natural mechanism that controls the cellular elimination and execution of unwanted cells from cell cycle progression as well as cell homeostasis [25]. Evading apoptosis can be markedly depicted as a hallmark of cancer and a common strategy for therapeutic target in cancer therapy [26]. Apoptosis is carried out by caspase activation, which are classical proteins that are exactly cleavaged target proteins in the apoptotic mechanism. Extrinsic and intrinsic pathways are commonly used to generate the activation by both intracellular and extracellular signals [27]. Dysregulation and delayed apoptosis are thought to play an important role in cancer development, leading to cancer evading program-cell death. There are numerous ways that cancer can evade apoptosis, including inhibited mutually caspase activation and disabled triggering apoptosis by up-regulation of BCL-2 apoptotic protein and loss of BAX and/or BAK expression [28]. The relative caspase-3 activities were significantly increased by $1.980 \pm 0.015,2.300 \pm$ $0.0003,2.607 \pm 0.003$, and $2.827 \pm 0.109(p<0.001)$, respectively, versus the control group without caspase- 3 inhibitor. In the presence of the caspase- 3 inhibitor, the relative caspase- 3 activities were significantly decreased to $1.300 \pm 0.0003,1.567 \pm 0.033,1.879 \pm 0.139$ and $2.149 \pm 0.082$, respectively, when compared with the non-caspase-3 inhibitor group (Figure 7(c)). These findings demonstrated that cyclopamine induced apoptosis in SW-620 cells is at least partly due to the activation of caspase-3 pathways.

(a)

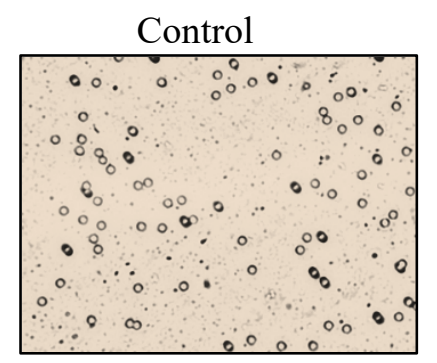

(b)

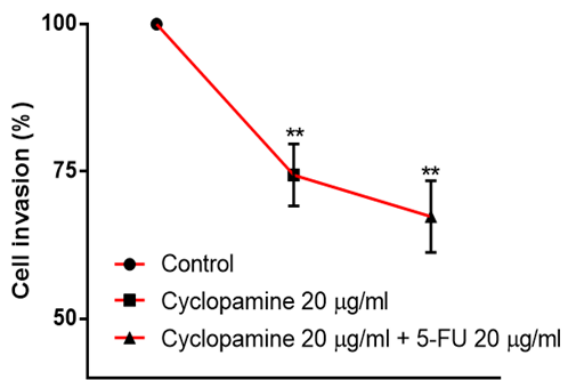

$\mathrm{Cm} 20 \mu \mathrm{g} / \mathrm{mL}$

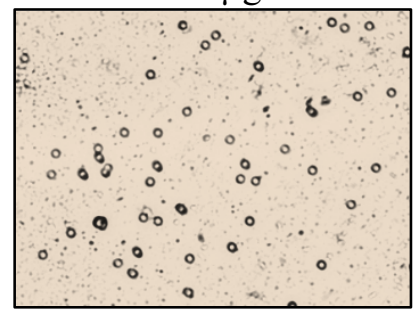

(c)
$\mathrm{Cm} 20 \mu \mathrm{g} / \mathrm{mL}+5-\mathrm{FU} 20 \mu \mathrm{g} / \mathrm{mL}$
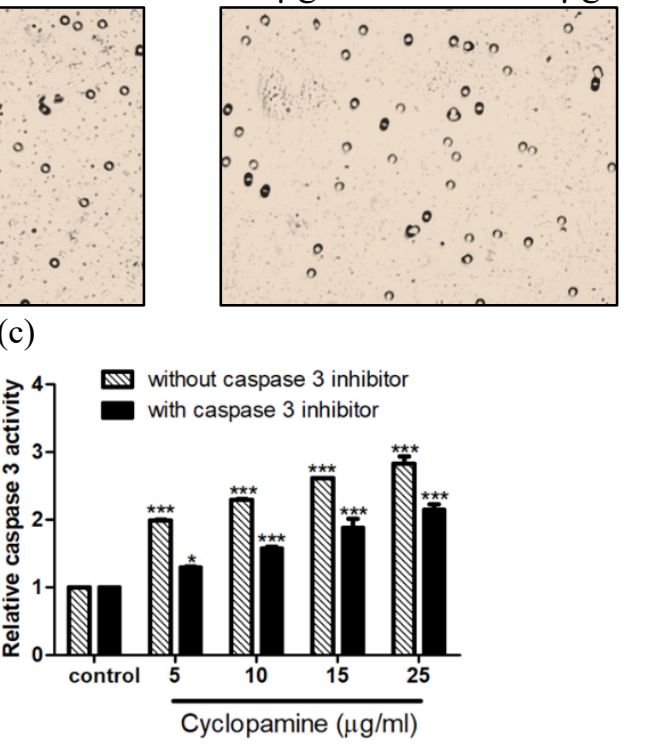

Figure 7 Effect of cyclopamine alone and in combination with 5-FU on cell invasion through the matrigel-coated invasion chamber in SW-620 cells. Cells which migrated through the matrigel invasion chamber at 100x magnification after being treated with cyclopamine alone or in co-treatment with 5-FU (Figures 7(a) - 7(b)). Caspase-3 activities were determined in SW-620 cells treated with the desired concentrations of cyclopamine. The caspase-3 enzymatic activity was evaluated with and without caspase- 3 inhibitor. The yellow color of p-nitroaniline (pNA) was determined by ELISA reader at $405 \mathrm{~nm}$ (Figure 7c). The data were expressed as Mean $\pm \operatorname{SEM}(\mathrm{n}=3)$. $* * * p<0.001$, significantly different from the control, $* p<0.05$, significantly different from the control 


\section{Effect of cyclopamine on cell growth in MRC-5 normal fibroblast cells}

As illustrated in Figure 8, the results showed the effect of cyclopamine on normal fibroblast cells. Normal cells did not receive a harmful toxicity of cyclopamine $(1,2.5,5 \mathrm{ug} / \mathrm{mL})$ after being treated for 24 h. However, $25 \mu \mathrm{g} / \mathrm{mL}$ of cyclopamine had the cytotoxic effect on normal fibroblast cells, with the percentage of cell viability approximately $53.48 \%$ at $25 \mu \mathrm{g} / \mathrm{mL}$ of cyclopamine. MRC-5 normal fibroblast cells were more sensitive to high doses of cyclopamine. Therefore, further study must investigate the harmful effect of cyclopamine on normal cells to clarify the safety of these compounds. However, the side effects on normal cell usually appear in chemotherapy when administered to cancer patients.

(a)

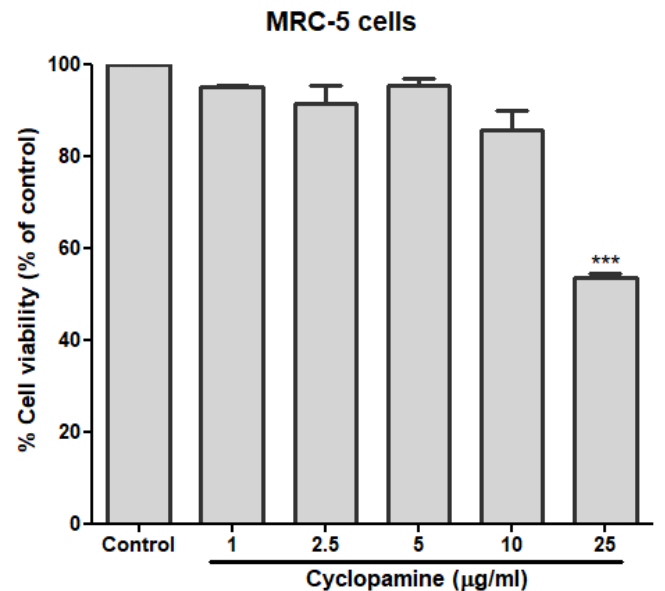

(b)

\begin{tabular}{cc}
\hline $\begin{array}{c}\text { Cyclopamine } \\
(\boldsymbol{\mu} \mathrm{g} / \mathbf{m L})\end{array}$ & $\begin{array}{c}\text { Mean } \pm \text { SEM } \\
(\%)\end{array}$ \\
\hline Control & $100.0 \pm 0.0$ \\
\hline 1 & $95.15 \pm 0.2300$ \\
\hline 2.5 & $91.47 \pm 3.926$ \\
\hline 5 & $95.61 \pm 1.483$ \\
\hline 10 & $85.69 \pm 4.312$ \\
\hline 25 & $53.48 \pm 1.134$ \\
\hline
\end{tabular}

Figure 8 Effect of cyclopamine on cell viability in MRC-5 normal fibroblast cells. Normal cells were tested with 1, 2.5, 5, 10 and $25 \mu \mathrm{g} / \mathrm{mL}$ of cyclopamine for $24 \mathrm{~h}$ (Figures 8(a) - 8(b)). Cell survival was measured via MTT cell viability assay. The data were expressed as Mean $\pm \operatorname{SEM}(\mathrm{n}=3)$. *** $p<0.001$, significantly different from the control

\section{Conclusions}

The results demonstrated that cyclopamine has synergistic drug-drug interactions in enhancing the anti-cancer effect of 5-FU on colorectal cancer cells and acts as anti-migrative and anti-invasive, and also affects caspase-3 activity, leading to repression of cancer metastasis and inducement of the apoptosis mechanism. However, the cellular mechanism underlying apoptosis induction should be further investigated in future models to clarify its synergism with 5-FU. Therefore, the preliminary study will provide basic knowledge to be expanded in future studies to clarify the underlying molecular mechanism in this present study. This will provide valuable data contributing to the generation of a human drug to be as for co-chemotherapy.

\section{Acknowledgements}

This work was fully supported by the Research Grant of Burapha University through the National Research Council of Thailand (Grant number 18/2559 and Grant number 169/2561) for Suwisit Manmuan. This work was provided with research equipment by the Faculty of Pharmaceutical Sciences, Burapha University, Thailand. The authors would like to thank all of the support staff of the Faculty of Pharmaceutical Sciences, Burapha University for their assistance and laboratory maintenance. 


\section{References}

[1] H Brenner, M Kloor and CP Pox. Colorectal cancer. Lancet 2014; 383, 1490-502.

[2] DB Longley and PG Johnston. Molecular mechanisms of drug resistance. J. Pathol. 2005; 205, $275-$ 92.

[3] JL Grem. 5-Fluorouracil: Forty-plus and still ticking. A review of its preclinical and clinical development. Invest. New Drugs 2000; 18, 299-313.

[4] DB Longley, DP Harkin and PG Johnston. 5-fluorouracil: Mechanisms of action and clinical strategies. Nat. Rev. Cancer 2003; 3, 330-8.

[5] S Giacchetti, B Perpoint, R Zidani, NL Bail, R Faggiuolo, C Focan, P Chollet, JF Llory, Y Letourneau, B Coudert, F Bertheaut-Cvitkovic, D Larregain-Fournier, AL Rol, S Walter, R Adam, JL Misset and F Lévi. Phase III multicenter randomized trial of oxaliplatin added to chronomodulated fluorouracil-leucovorin as first-line treatment of metastatic colorectal cancer. $J$. Clin. Oncol. 2000; 18, 136-47.

[6] JY Douillard, D Cunningham, AD Roth, M Navarro, RD James, P Karasek, P Jandik, T Iveson, J Carmichael, M Alakl, G Gruia, L Awad and P Rougier. Irinotecan combined with fluorouracil compared with fluorouracil alone as first-line treatment for metastatic colorectal cancer: A multicentre randomised trial. Lancet 2000; 355, 1041-7.

[7] FM Santandreu, A Valle, J Oliver and P Roca. Resveratrol potentiates the cytotoxic oxidative stress induced by chemotherapy in human colon cancer cells. Cell Physiol. Biochem. 2011; 28, 219-28.

[8] MW Turner, R Cruz, J Mattos, N Baughman, J Elwell, J Fothergill, A Nielsen, J Brookhouse, A Bartlett, P Malek, X Pu, MD King and OM McDougal. Cyclopamine bioactivity by extraction method from Veratrum californicum. Bioorg. Med. Chem. 2016; 24, 3752-7.

[9] J Taipale, JK Chen, MK Cooper, B Wang, RK Mann, L Milenkovic, MP Scott and PA Beachy. Effects of oncogenic mutations in Smoothened and Patched can be reversed by cyclopamine. Nature 2000; 406, 1005-9.

[10] H Ma, HQ Li and X Zhang. Cyclopamine, a naturally occurring alkaloid, and its analogues may find wide applications in cancer therapy. Curr. Top. Med. Chem. 2013; 13, 2208-15.

[11] P Heretsch, L Tzagkaroulaki and A Giannis. Cyclopamine and hedgehog signaling: Chemistry, biology, medical perspectives. Angew. Chem. Int. Ed. Engl. 2010; 49, 3418-27.

[12] Z Shafaee, H Schmidt, W Du, M Posner and R Weichselbaum. Cyclopamine increases the cytotoxic effects of paclitaxel and radiation but not cisplatin and gemcitabine in Hedgehog expressing pancreatic cancer cells. Cancer Chemother. Pharmacol. 2006; 58, 765-70.

[13] S Mukherjee, N Frolova, A Sadlonova, Z Novak, A Steg, GP Page, DR Welch, SM Lobo-Ruppert, JM Ruppert, MR Johnson and AR Frost. Hedgehog signaling and response to cyclopamine differ in epithelial and stromal cells in benign breast and breast cancer. Cancer Biol. Ther. 2006; 5, 674-83.

[14] M Mimeault, SL Johansson, JP Henichart, P Depreux and SK Batra. Cytotoxic effects induced by docetaxel, gefitinib, and cyclopamine on side population and nonside population cell fractions from human invasive prostate cancer cells. Mol. Cancer Ther. 2010; 9, 617-30.

[15] S Eimer, F Dugay, K Airiau, T Avril, V Quillien, MA Belaud-Rotureau and F Belloc. Cyclopamine cooperates with EGFR inhibition to deplete stem-like cancer cells in glioblastoma-derived spheroid cultures. Neuro. Oncol. 2012; 14, 1441-51.

[16] SA Almawash, G Mondal and RI Mahato. Coadministration of polymeric conjugates of docetaxel and cyclopamine synergistically inhibits orthotopic pancreatic cancer growth and metastasis. Pharm. Res. 2018; 35, 17.

[17] ST Lee, KD Welch, KE Panter, DR Gardner, M Garrossian and CW Chang. Cyclopamine: From cyclops lambs to cancer treatment. J. Agr. Food Chem. 2014; 62, 7355-62.

[18] T Kawahara, N Kawaguchi-Ihara, Y Okuhashi, M Itoh, N Nara and S Tohda. Cyclopamine and quercetin suppress the growth of leukemia and lymphoma cells. Anticancer Res. 2009; 29, 4629-32.

[19] YZ Feng, T Shiozawa, T Miyamoto, H Kashima, M Kurai, A Suzuki, J Ying-Song and I Konishi. Overexpression of hedgehog signaling molecules and its involvement in the proliferation of endometrial carcinoma cells. Clin. Cancer Res. 2007; 13, 1389-98.

[20] J Warzecha, L Bonke, U Koehl, D Munkelt, S Gottig, D Percic, M Arabmotlagh and A Kurth. The hedgehog inhibitor cyclopamine induces apoptosis in leukemic cells in vitro. Leuk Lymphoma 2008; 49, 2383-6.

[21] B Zhang, H Wang, T Jiang, K Jin, Z Luo, W Shi, H Mei, H Wang, Y Hu, Z Pang and X Jiang. Cyclopamine treatment disrupts extracellular matrix and alleviates solid stress to improve nanomedicine delivery for pancreatic cancer. J. Drug Target. 2018; 26, 913-9. 
[22] D Qualtrough, P Rees, B Speight, AC Williams and C Paraskeva. The hedgehog inhibitor cyclopamine reduces beta-catenin-Tcf transcriptional activity, induces E-cadherin expression, and reduces invasion in colorectal cancer cells. Cancers (Basel) 2015; 7, 1885-99.

[23] J Che, FZ Zhang, CQ Zhao, XD Hu and SJ Fan. Cyclopamine is a novel hedgehog signaling inhibitor with significant anti-proliferative, anti-invasive and anti-estrogenic potency in human breast cancer cells. Oncol. Lett. 2013; 5, 1417-21.

[24] S Elmore. Apoptosis: A review of programmed cell death. Toxicol Pathol. 2007; 35, 495-516.

[25] R Jan and GE Chaudhry. Understanding apoptosis and apoptotic pathways targeted cancer therapeutics. Adv. Pharm. Bull. 2019; 9, 205-18.

[26] K Fernald and M Kurokawa. Evading apoptosis in cancer. Trends Cell Biol. 2013; 23, 620-33.

[27] L Portt, G Norman, C Clapp, M Greenwood and MT Greenwood. Anti-apoptosis and cell survival: A review. Biochim. Biophys. Acta 2011; 1813, 238-59.

[28] J Plati, O Bucur and R Khosravi-Far. Dysregulation of apoptotic signaling in cancer: Molecular mechanisms and therapeutic opportunities. J. Cell Biochem. 2008; 104, 1124-49. 